\title{
Transfer of Pantoea citrea, Pantoea punctata and Pantoea terrea to the genus Tatumella emend. as Tatumella citrea comb. nov., Tatumella punctata comb. nov. and Tatumella terrea comb. nov. and description of Tatumella morbirosei sp. nov.
}

\author{
Carrie L. Brady, ${ }^{1}$ Stephanus N. Venter, ${ }^{1}$ Ilse Cleenwerck, ${ }^{2}$ \\ Katrien Vandemeulebroecke, ${ }^{2}$ Paul De Vos ${ }^{2}$ and Teresa A. Coutinho ${ }^{1}$ \\ ${ }^{1}$ Department of Microbiology and Plant Pathology, Forestry and Agricultural Biotechnology Institute \\ (FABI), University of Pretoria, Pretoria 0002, South Africa \\ ${ }^{2}$ BCCM/LMG Bacteria Collection, Ghent University, K.L. Ledeganckstraat 35, B-9000 Ghent, \\ Belgium
}

Correspondence Teresa A. Coutinho teresa.coutinho@fabi.up.ac.za

\begin{abstract}
Pantoea citrea, Pantoea punctata and Pantoea terrea were described for strains isolated from fruit and soil originating in Japan. These three 'Japanese' species have been shown to be phylogenetically distant from other species of the genus Pantoea. It has been observed previously that, using multilocus sequence analysis (MLSA), the 'Japanese' species consistently formed a distinct clade with an extended branch length, casting doubt on the inclusion of these species within the genus Pantoea. Furthermore, the 'Japanese' species are closely related to Tatumella ptyseos, strains of which originate from human clinical specimens. DNA-DNA hybridization and phenotypic tests confirmed the observed phylogenetic distance of $P$. citrea, $P$. punctata and $P$. terrea from the genus Pantoea and the affiliation of these species with Tatumella. In addition, strains causing pink disease of pineapple, identified previously as $P$. citrea, were shown to represent a separate species by using $16 \mathrm{~S}$ rRNA gene sequence analysis, and MLSA and DNADNA hybridization data. The name Tatumella morbirosei sp. nov. with the type strain LMG $23360^{\top}$ $\left(=\mathrm{BD} 878^{\top}=\mathrm{NCPPB} 4036^{\top}=\mathrm{CMC6}^{\top}\right)$ is proposed to accommodate these strains. The new combinations Tatumella citrea (Kageyama et al. 1992) comb. nov. (type strain, SHS $2003^{\top}=$ ATCC $31623^{\top}=$ BD $875^{\top}=$ CCUG $30156^{\top}=$ CIP $105599^{\top}=$ DSM $13699^{\top}=J C M$ $8882^{\top}=$ LMG $22049^{\top}$ ), Tatumella punctata (Kageyama et al. 1992) comb. nov. (type strain, SHS

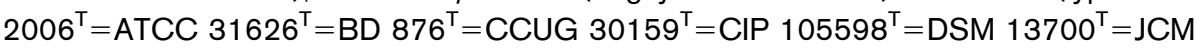
$8885^{\top}=$ LMG $22050^{\top}$ ) and Tatumella terrea (Kageyama et al. 1992) comb. nov. (type strain, SHS $2008^{\top}=$ ATCC $31628^{\top}=$ BD $877^{\top}=$ CCUG $30161^{\top}=$ CIP $105600^{\top}=$ DSM $13701^{\top}=J C M$ $8887^{\top}=$ LMG $22051^{\top}$ ) are proposed for $P$. citrea, $P$. punctata and $P$. terrea, respectively.
\end{abstract}

Abbreviations: atpD, ATP synthase $\beta$-subunit; DKGA, 2,5-diketo-Dgluconic acid; gyrB, DNA gyrase; infB, initiation translation factor 2; MLSA, multilocus sequence analysis; $r p o B$, RNA polymerase $\beta$-subunit.

The GenBank/EMBL/DDBJ accession numbers for the $16 \mathrm{~S}$ rRNA gene sequences of Tatumella ptyseos LMG $7888^{\top}$, Tatumella punctata LMG $22050^{\top}$, Tatumella terrea LMG $22051^{\top}$, Tatumella citrea LMG $22049^{\top}$ and Tatumella morbirosei LMG 23360 ${ }^{\top}$ and LMG 23359 are EU344770, EF688006-EF688008, EU344769 and FJ617235, respectively.

A table showing the signature nucleotides of the 16S rRNA and atpD gene sequences for the differentiation of Tatumella species from Pantoea species is available as supplementary material with the online version of this paper.
Following the proposal of the novel genus Pantoea in 1989 (Gavini et al., 1989), but preceding the transfer of Erwinia ananas and Erwinia stewartii to Pantoea (Mergaert et al., 1993), three novel Pantoea species from fruit and soil samples in Japan that produced 2,5-diketo-D-gluconic acid (DKGA) from D-glucose were described (Kageyama et al., 1992). Pantoea citrea, Pantoea punctata and Pantoea terrea were included in the genus Pantoea based on general phenotypic data and DNA-DNA hybridization values, despite the inability of the original Pantoea species to produce DKGA. Until recently, no phylogenetic study had been performed on all Pantoea species with validly published names, giving no reason to doubt the inclusion 
of $P$. citrea, $P$. punctata and $P$. terrea in the genus Pantoea. However, the most recent edition of Bergey's Manual of Systematic Bacteriology (Grimont \& Grimont, 2005) states that more taxonomic work is required to justify the assignment of these three species to the genus Pantoea. A recent phylogenetic study of the Enterobacteriaceae revealed an atpD (ATP synthase $\beta$-subunit) sequence indel that was specific to Pantoea and Tatumella (Paradis et al., 2005), indicating a close phylogenetic relationship between these two genera. This was in agreement with the initial suggestion of P. Grimont that the 'Japanese' species might be more similar to Tatumella ptyseos than Pantoea in their nutritional patterns (Kageyama et al., 1992). The single species genus Tatumella was created for clinical strains isolated in North and South America between 1960 and 1980 (Hollis et al., 1981). A multilocus sequence analysis (MLSA) scheme based on gyrB (DNA gyrase), $r p o B$ (RNA polymerase $\beta$-subunit), atpD and infB (initiation translation factor 2) genes was performed recently on 102 Pantoea strains including the 'Japanese' species and $T$. ptyseos (Brady et al., 2008). A concatenated tree constructed from the sequences of the four genes was found to be the most robust approach for revealing phylogenetic relationships amongst Pantoea strains. The MLSA study indicated a clear phylogenetic divergence between $P$. citrea, $P$. punctata and $P$. terrea and the remaining Pantoea species, and confirmed T. ptyseos as a close phylogenetic relative of the 'Japanese' species. It was concluded that the 'Japanese' species should be transferred to the genus Tatumella. A similar study based on multilocus typing of Pantoea species using six protein-coding genes was in agreement regarding the taxonomic position of the 'Japanese' species and also suggested the reclassification of these three species as Tatumella (Delétoile et al., 2009).

\section{Isolation of strains}

Strains used in this study were obtained from the BCCM/ LMG Bacteria Collection (http://www.belspo.be/bccm) and the Centers for Disease Control, Atlanta, Georgia, USA, and are listed in Table 1. An alkali extraction method (Niemann et al., 1997) was used to isolate genomic DNA from the strains, which was stored at $-20{ }^{\circ} \mathrm{C}$.

\section{$16 S$ rRNA gene sequencing}

Almost-complete 16S rRNA genes were sequenced for the type strains of $P$. citrea (LMG $22049^{\mathrm{T}}$ ), $P$. punctata (LMG $22050^{\mathrm{T}}$ ) and $P$. terrea (LMG $22051^{\mathrm{T}}$ ), and additional $P$. citrea strains (LMG 23359 and LMG $23360^{\mathrm{T}}$ ), which were found to cause pink disease of pineapple (Cha et al., 1997), using the primers and conditions determined by Coenye et al. (1999). The sequences were aligned using CLUSTAL_X (Thompson et al., 1997) and the overhangs were trimmed. The MODELltest 3.7 program (Posada \& Crandall, 1998) was then applied to determine the best-fit evolutionary model. Maximum-likelihood and neighbourjoining analyses were performed using PHYML (Guindon \&
Gascuel, 2003) and PAUP 4.0b10 (Swofford, 2000), respectively, by applying the models and parameters determined by MODELLTEST (only maximum-likelihood phylogenetic trees are shown). Bootstrap analysis with 1000 replicates was performed to assess the support for these clusters.

In the 16S rRNA gene sequence tree (Fig. 1) the genus Pantoea is split phylogenetically, although this is not unusual as Pantoea has been shown to be polyphyletic (Brady et al., 2008). The majority of the Pantoea 'core' species are contained in a cluster supported by high bootstrap support, whereas Pantoea dispersa and a Pantoea species from the Brenner DNA group IV cluster amongst Erwinia species. The 'Japanese' species are situated in a distinctly separate clade with a different branch point, also with high bootstrap support. These findings support those of Grimont \& Grimont (2005), based on 16S rRNA gene and $r p o B$ sequence comparisons, that the 'Japanese' species cluster at a lower level to the Pantoea 'core' clade. Interestingly, LMG $7888^{\mathrm{T}}$, the type strain of T. ptyseos, clustered closely with the type strain of $P$. terrea, within the 'Japanese' species clade, prompting further examination of the relationship of the 'Japanese' species with $T$. ptyseos. The additional $P$. citrea strains LMG 23359 and LMG $23360^{\mathrm{T}}$, which cause pink disease of pineapple, do not cluster with the type strain of this species (LMG $22049^{\mathrm{T}}$ ), but are found on a separate branch, suggesting that these strains do not belong to $P$. citrea. The 16S rRNA gene sequence similarity of strain LMG $23360^{\mathrm{T}}$ was greater than $98 \%$ to the type strains of $P$. punctata, P. citrea, Pantoea sp. (Brenner DNA group II) and T. ptyseos.

\section{gyrB, rpoB, atpD and infB gene sequencing}

MLSA was performed on all strains, as described previously (Brady et al., 2008), to provide further support for the reclassification of the 'Japanese' species. Sequence analysis and tree construction were performed as described above. Several Erwinia species were included in the MLSA study and housekeeping gene sequences for Erwinia tasmaniensis, Escherichia coli, Shigella dysenteriae, Klebsiella pneumoniae, Citrobacter rodentium, Citrobacter koseri and Cronobacter sakazakii were obtained from genome sequencing databases (http://www.ncbi.nlm.nih.gov, http://www.sanger.ac.uk, https://asap.ahabs.wisc.edu/asap/home.php). In Fig. 2, a MLSA phylogenetic tree based on the concatenated sequences of $g y r B, r p o B$, atpD and $\operatorname{infB}$ genes, Pantoea strains formed a monophyletic cluster within the Enterobacteriaceae. This cluster contained two sublineages that were supported by high bootstrap values of $100 \%$. The first sublineage contains the Pantoea 'core' species including Brenner DNA groups II, IV and V. The second sublineage consists of the 'Japanese' species and the type strain of $T$. ptyseos. The type strain of $T$. ptyseos clustered closely with $P$. terrea strains, specifically with strain LMG 23565 and its duplicate CCUG 30163. This result indicates that LMG 23565 (=CCUG 30163) was erroneously classified and in 
Table 1. Strains of Tatumella and Pantoea used in this study

ATCC, American Type Culture Collection, Rockville, Maryland, USA; BD, Plant Pathogenic and Plant Protecting Bacteria (PPPPB) Culture Collection, ARC-PPRI, Pretoria, South Africa; Br HG, Brenner hybridization group; CCUG, Culture Collection, University of Göteborg, Sweden; LMG, BCCM/LMG Bacteria Collection, Ghent University, Belgium. R, Reference strain.

\begin{tabular}{|c|c|c|c|c|c|c|c|}
\hline Species & Strain & Source & Location & $g y r B^{\star}$ & $r p o B^{*}$ & $\operatorname{atp} D^{*}$ & $\operatorname{infB} B^{*}$ \\
\hline Tatumella morbirosei & LMG $23360^{\mathrm{T}}=\mathrm{BD} 878^{\mathrm{T}}$ & Pineapple & Philippines & EU344760 & EU344768 & EU344756 & EU344764 \\
\hline \multirow[t]{6}{*}{ Tatumella punctata } & LMG $22050^{\mathrm{T}}=\mathrm{BD} 876^{\mathrm{T}}$ & Mandarin orange & Japan & EF988803 & EF988975 & EF988716 & EF988889 \\
\hline & LMG 22097 & Mandarin orange & Japan & EF988805 & EF988977 & EF988718 & EF988891 \\
\hline & LMG 22098 & Persimmon & Japan & EF988806 & EF988978 & EF988719 & EF988892 \\
\hline & LMG 23563 & Mandarin orange & Japan & EF988808 & EF988980 & EF988721 & EF988894 \\
\hline & CCUG 30157 & Mandarin orange & Japan & EF988795 & EF988967 & EF988708 & EF988881 \\
\hline & CCUG 30160 & Mandarin orange & Japan & EF988796 & EF988968 & EF988709 & EF988882 \\
\hline \multirow[t]{3}{*}{ Tatumella terrea } & LMG $22051^{\mathrm{T}}=\mathrm{BD} 877^{\mathrm{T}}$ & Soil & Japan & EF988804 & EF988976 & EF988717 & EF988890 \\
\hline & LMG 23564 & Soil & Japan & EF988809 & EF988981 & EF988722 & EF988895 \\
\hline & CCUG 30162 & Soil & Japan & EF988797 & EF988969 & EF988710 & EF988883 \\
\hline Pantoea agglomerans & LMG 2660 & Wisteria floribunda & Japan & EF988823 & EF988995 & EF988736 & EF988909 \\
\hline \multirow[t]{2}{*}{ Pantoea ananatis } & LMG $2665^{\mathrm{T}}$ & Pineapple & Brazil & EF988824 & EF988996 & EF988737 & EF988910 \\
\hline & LMG 20103 & Eucalyptus & South Africa & EF988799 & EF988971 & EF988712 & EF988885 \\
\hline \multirow{2}{*}{$\begin{array}{l}\text { Pantoea stewartii subsp. } \\
\text { stewartii }\end{array}$} & LMG $2715^{\mathrm{T}}$ & Maize & USA & EF988831 & EF989003 & EF988744 & EF988917 \\
\hline & LMG 2718 & Maize & USA & EF988832 & EF989004 & EF988745 & EF988918 \\
\hline \multirow{2}{*}{$\begin{array}{l}\text { Pantoea stewartii subsp. } \\
\text { indologenes }\end{array}$} & LMG $2632^{\mathrm{T}}$ & Fox millet & India & EF988822 & EF988994 & EF988735 & EF988908 \\
\hline & LMG 2673 & Pineapple & Hawaii & EF988827 & EF988999 & EF988740 & EF988914 \\
\hline \multirow[t]{2}{*}{ Pantoea dispersa } & LMG $2603^{\mathrm{T}}$ & Soil & Japan & EF988818 & EF988990 & EF988731 & EF988904 \\
\hline & LMG 2604 & Wild rose & Netherlands & EF988819 & EF988991 & EF988732 & EF988905 \\
\hline \multirow[t]{2}{*}{ Pantoea sp. (Br HG II) } & LMG $5345^{\mathrm{R}}$ & Human, stool & New Jersey, USA & EU145272 & EU145304 & EU145256 & EU145288 \\
\hline & LMG 24526 & Human, blood & New York, USA & EU145261 & EU145293 & EU145245 & EU145277 \\
\hline \multirow[t]{2}{*}{ Pantoea sp. (Br HG IV) } & LMG $2781^{\mathrm{R}}$ & Human, trachea & Connecticut, USA & EU145271 & EU145303 & EU145255 & EU145287 \\
\hline & LMG 24529 & Human, cyst & Georgia, USA & EU145264 & EU145296 & EU145248 & EU145280 \\
\hline \multirow[t]{2}{*}{ Pantoea sp. (Br HG V) } & LMG $5343^{\mathrm{R}}$ & Human, urethra & Montana, USA & EU145270 & EU145302 & EU145254 & EU145286 \\
\hline & LMG 24532 & Human, sputum & Wisconsin, USA & EU145267 & EU145299 & EU145251 & EU145283 \\
\hline Pantoea sp. (Br HG V) & LMG $24534^{\mathrm{R}}$ & Human, blood & Paris, France & EU145269 & EU145301 & EU145253 & EU145285 \\
\hline Erwinia billingiae & LMG $2613^{\mathrm{T}}$ & Pear & UK & EU145275 & EU145307 & EU145259 & EU145291 \\
\hline Erwinia psidii & LMG 7034 & Guava & Brazil & FJ187834 & FJ187844 & FJ187829 & FJ187839 \\
\hline Erwinia rhapontici & LMG $2688^{\mathrm{T}}$ & Rhubarb & UK & EF988838 & EF989010 & EF988751 & EF988924 \\
\hline Erwinia toletana & LMG $24162^{\mathrm{T}}$ & Olive tree & Spain & EU145274 & EU145306 & EU145258 & EU145290 \\
\hline
\end{tabular}

${ }^{\star}$ GenBank accession numbers. 


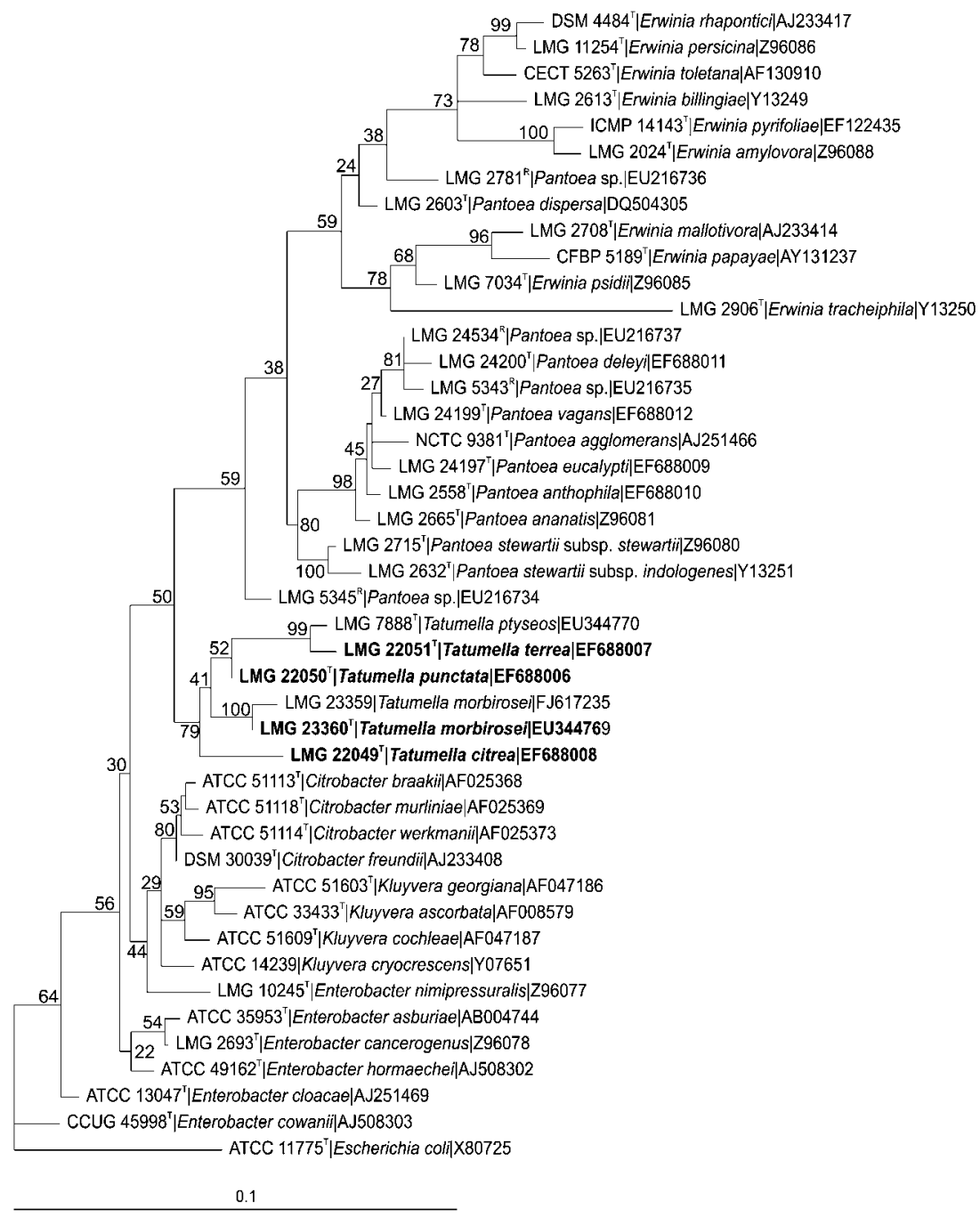

Fig. 1. Maximum-likelihood tree based on $16 \mathrm{~S}$ rRNA gene sequences of Tatumella species. Percentage bootstrap values based on 1000 replicates are given at nodes. The sequence of Escherichia coli ATCC $11775^{\top}$ was included as an outgroup. R, Reference strain. Bar, 0.1 substitutions per nucleotide position. fact belongs to T. ptyseos. LMG 23359 and LMG $23360^{\mathrm{T}}$, two supposed $P$. citrea strains causing pink disease of pineapple referred to as MLSA group J (Brady et al., 2008), grouped with LMG $22049^{\mathrm{T}}$, the type strain of $P$. citrea but were situated on a separate branch with a long branch length. This supports the probability that these two strains do not belong to P. citrea, but to a novel species. All species clustered within both sublineages of Pantoea were supported with $100 \%$ bootstrap values. All four housekeeping- and 16S rRNA gene sequences were examined for heterogeneous nucleotides that could be used as signature nucleotide positions to differentiate between Tatumella and Pantoea. Eight signature nucleotides were identified in the 16S rRNA gene sequences that differ between Tatumella and Pantoea. The gene sequences of atpD revealed the most heterogeneity with 23 signature nucleotides, which are conserved in Tatumella species and differ from all Pantoea species. The signature nucleotides for the $16 \mathrm{~S}$ rRNA and atpD genes are listed in Supplementary Table S1 (available in IJSEM Online). The Escherichia coli numbering positions were used to designate the nucleotide positions (Brosius et al., 1978; http://www.ncbi.nlm.nih. gov).

\section{DNA-DNA hybridization}

High quality DNA for DNA-DNA hybridization of strains was prepared by using the method of Wilson (1987), with minor modifications (Cleenwerck et al., 2002). DNA-DNA hybridizations were performed using the microplate method (Ezaki et al., 1989) with some modifications (Cleenwerck et al., 2002). The hybridization temperature was $45^{\circ} \mathrm{C} \pm 1{ }^{\circ} \mathrm{C}$, reciprocal reactions $(\mathrm{A} \times \mathrm{B}$ and $\mathrm{B} \times \mathrm{A})$ were performed for each DNA pair from all strains and their variation was within the limits of this method (Goris et al., 1998). The values presented were based on a minimum of four replicates. Representative strains from each 'Japanese' Pantoea species were selected for hybridization based on the 16S rRNA gene and MLSA phylogenetic trees. The type strains of the 'Japanese' species were hybridized with each other, and with the type strain of T. ptyseos, their closest phylogenetic neighbour, as 


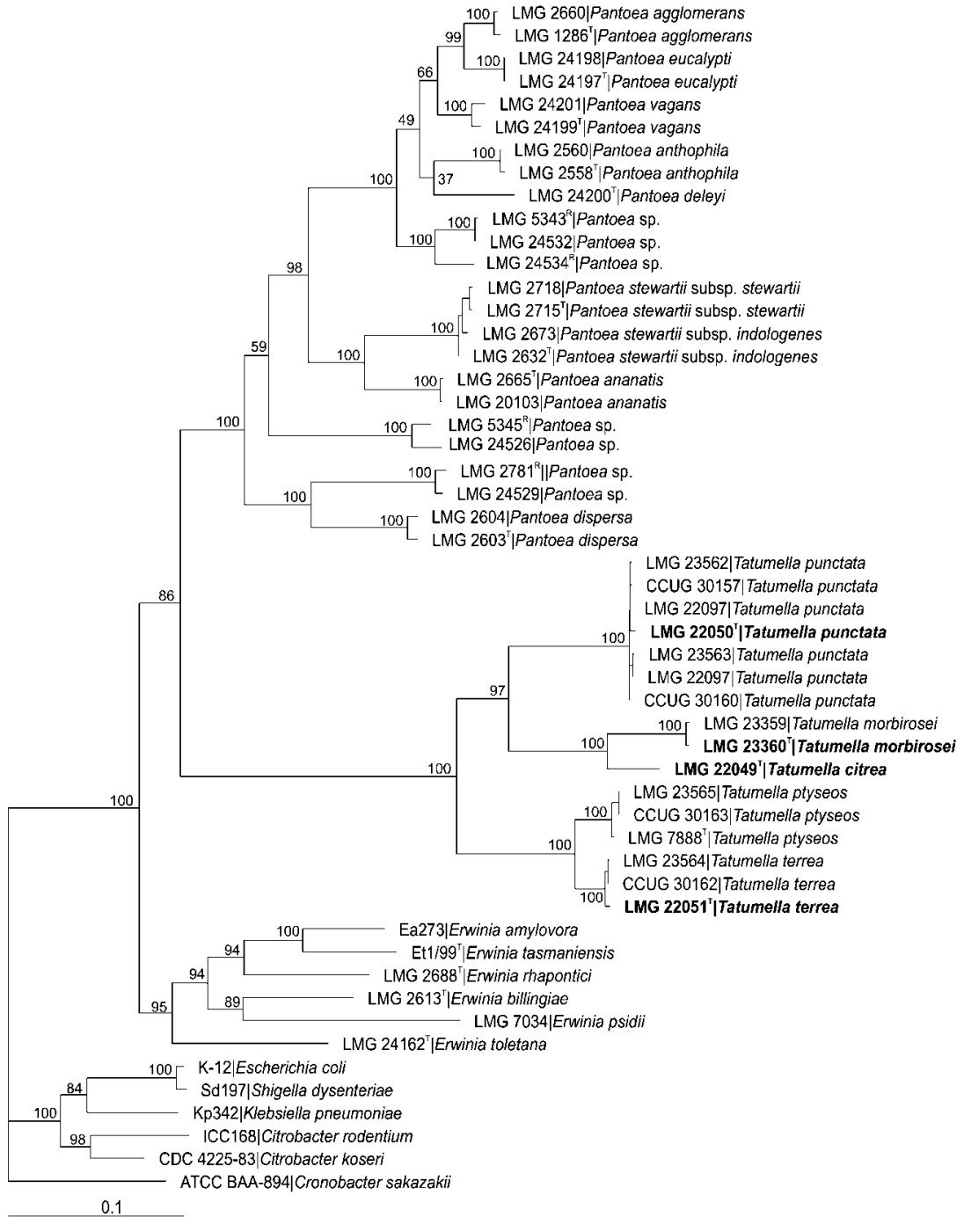

Fig. 2. Maximum-likelihood tree based on the concatenated nucleotide sequences of $g y r B$, $r p o B$, atp $D$ and infB genes of Tatumella and Pantoea strains. Percentage bootstrap values based on 1000 replicates are given at nodes. The sequence of Cronobacter sakazakii was included as an outgroup. Sequences for Erwinia tasmaniensis, Escherichia coli, Shigella dysenteriae, Klebsiella pneumoniae, Citrobacter rodentium, Citrobacter koseri and Cronobacter sakazakii were obtained from genome sequencing databases (http://www. ncbi.nlm.nih.gov, http://www.sanger.ac.uk, https://asap.ahabs.wisc.edu/asap/home.php). $\mathrm{R}$, Reference strain. Bar, 0.1 substitutions per nucleotide position. well as with the type strains of Pantoea agglomerans, Pantoea ananatis, Pantoea vagans, Pantoea stewartii subsp. stewartii and $P$. dispersa. A summary of the hybridization results is presented in Table 2. The DNA-DNA relatedness between P. citrea LMG $22049^{\mathrm{T}}$, P. punctata LMG $22050^{\mathrm{T}}$ and $P$. terrea LMG $22051^{\mathrm{T}}$ ranged from 13 to $21 \%$, which was considerably lower than the $28-43 \%$ reported by Kageyama et al. (1992) and could be due to different hybridization methods used. LMG 23359 and LMG $23360^{\mathrm{T}}$, the strains that can cause pink disease of pineapple (Cha et al., 1997) shared $96 \%$ DNA-DNA relatedness when hybridized against each other, whereas strain LMG $23360^{\mathrm{T}}$ displayed only $42 \%$ DNA-DNA relatedness with $P$. citrea LMG $22049^{\mathrm{T}}$. These results together with the $16 \mathrm{~S}$ rRNA gene sequence and MLSA data proved that strains LMG $23360^{\mathrm{T}}$ and LMG 23359 do not belong to $P$. citrea.

P. citrea LMG $22049^{\mathrm{T}}$ and P. punctata LMG $22050^{\mathrm{T}}$ displayed 14 and $21 \%$ DNA-DNA relatedness when hybridized with $T$. ptyseos LMG $7888^{\mathrm{T}}$, respectively. In contrast, the T. ptyseos type strain shared $66 \%$ DNA-DNA relatedness with $P$. terrea LMG $22051^{\mathrm{T}}$ and $87 \%$ with LMG 23565 , originally considered to be $P$. terrea. Strain LMG 23565 demonstrated only 55\% DNA-DNA relatedness, when hybridized with $P$. terrea LMG $22051^{\mathrm{T}}$. These results are in favour of the reclassification of strain LMG 23565 (=CCUG 30163) as T. ptyseos and confirm the close phylogenetic relationship between $P$. terrea and T. ptyseos, observed in both the 16S rRNA gene and MLSA phylogenetic trees (Figs 1 and 2). The DNA-DNA relatedness between the type strains of the 'Japanese' Pantoea species and the type strains of $P$. agglomerans, $P$. ananatis, $P$. vagans, $P$. stewartii and $P$. dispersa was below $10 \%$. These low hybridization values were also reflected in the phylogenetic distance between the 'Japanese' species and the Pantoea 'core' species in both Figs 1 and 2.

\section{DNA G+C content}

The DNA $\mathrm{G}+\mathrm{C}$ content of the type strains, determined by HPLC (Mesbah et al., 1989), were as follows: P. citrea 
Table 2. DNA-DNA hybridization values between T. citrea comb. nov., T. morbirosei sp. nov., T. punctata comb. nov., T. terrea comb. nov., T. ptyseos and selected species belonging to Pantoea

\begin{tabular}{|c|c|c|c|c|c|c|c|c|c|c|c|c|c|c|}
\hline \multirow[t]{2}{*}{ Strain } & \multicolumn{14}{|c|}{ Hybridization (\%) with ${ }^{3} \mathrm{H}$-labelled DNA from: } \\
\hline & 1 & 2 & 3 & 4 & 5 & 6 & 7 & 8 & 9 & 10 & 11 & 12 & 13 & 14 \\
\hline 2. Tatumella morbirosei LMG $23360^{\mathrm{T}}$ & 42 & 100 & & & & & & & & & & & & \\
\hline 3. Tatumella morbirosei LMG 23359 & & 96 & 100 & & & & & & & & & & & \\
\hline 4. Tatumella punctata LMG $22050^{\mathrm{T}}$ & 21 & 17 & & 100 & & & & & & & & & & \\
\hline 7. Tatumella terrea LMG 23564 & & & & & & 82 & 100 & & & & & & & \\
\hline 8. Tatumella ptyseos LMG $7888^{\mathrm{T}}$ & 14 & 15 & & 21 & & 66 & & 100 & & & & & & \\
\hline 9. Tatumella ptyseos LMG 23565 & 15 & 13 & & 20 & & 55 & 54 & 87 & 100 & & & & & \\
\hline 10. Pantoea agglomerans LMG $1286^{\mathrm{T}}$ & 6 & & & 8 & & 8 & & & & 100 & & & & \\
\hline 11. Pantoea ananatis LMG $2665^{\mathrm{T}}$ & 5 & & & 6 & & 6 & & & & 21 & 100 & & & \\
\hline
\end{tabular}

$\left(\right.$ LMG 22049 $\left.{ }^{\mathrm{T}}\right), 49.8$ mol\%; MLSA group J (LMG 23360 $)$, $50.2 \mathrm{~mol} \%$; P. punctata (LMG 22050 ${ }^{\mathrm{T}}$, LMG 22098), $50.7 \mathrm{~mol} \%$; P. terrea (LMG $22051^{\mathrm{T}}$, LMG 23564), 52.6$52.8 \mathrm{~mol} \%$; and T. ptyseos (LMG $7888^{\mathrm{T}}$, LMG 23565), 51.7-52.1 mol\%.

\section{Phenotypic assays}

Differences between the Pantoea 'core' species and the 'Japanese' species have been noted previously, not only phylogenetically but also phenotypically (Grimont \& Grimont, 2005; Delétoile et al., 2009). API 20E, API 50 $\mathrm{CHB} / \mathrm{E}$, Biotype 100 (bioMérieux) and GN2 MicroPlate (Biolog) tests were performed on all Tatumella and Pantoea strains used in this study, to verify that the phenotypic data agree with those available in the literature. Cell suspensions were prepared from strains grown on tryptone soya agar (Oxoid) for $12 \mathrm{~h}$. All phenotypic test strips and plates were incubated for $24-48 \mathrm{~h}$ at $28{ }^{\circ} \mathrm{C}$, except the Biotype 100 strips which were incubated for up to 6 days. Scoring was performed according to the manufacturer's instructions. Phenylalanine deaminase activity was determined by adding $10 \%$ aqueous $\mathrm{FeCl}_{3}$ to $24 \mathrm{~h}$ cultures grown on (D)phenylalanine agar (Merck). The development of a green colour indicated a positive reaction. A high correlation was observed between the phenotypic results generated in this study, the phenotypic data presented in Bergey's Manual of Systematic Bacteriology (Grimont \& Grimont, 2005) and the original species descriptions of $P$. citrea, P. punctata and $P$. terrea (Kageyama et al., 1992) and T. ptyseos (Hollis et al., 1981). T. ptyseos and the 'Japanese' species could be distinguished from the genus Pantoea by means of a positive reaction for arginine dihydrolase (except $P$. terrea and T. ptyseos) and 2-ketogluconate dehydrogenase, their inability to produce acid from arbutin, myo-inositol and L-rhamnose and their inability to utilize D-galacturonic acid,
D-glucuronic acid, myo-inositol, methyl $\beta$-D-glucoside, Lrhamnose, D-saccharic acid and meso-tartrate (except $T$. ptyseos). A summary of the most useful phenotypic and biochemical characteristics for differentiating $T$. ptyseos and the 'Japanese' species from Pantoea species is presented in Table 3. Table 3 was assembled using data generated in this study (except for DKGA), of which the majority agreed with that published previously.

A summary of biochemical and phenotypic characteristics that can be used to differentiate between $T$. ptyseos, the 'Japanese' species and the pink disease-causing strains LMG $23360^{\mathrm{T}}$ and LMG 23359 is given in Table 4. The strains causing pink disease of pineapple could be differentiated from $P$. citrea by means of a positive phenylalanine deaminase reaction, acid production from starch, their ability to utilize adonitol and trigonelline, and their inability to utilize gentiobiose and lactulose. P. terrea could be differentiated from $T$. ptyseos, its closest phylogenetic neighbour, by means of a negative phenylalanine deaminase reaction, the ability to utilize formic acid and pyruvic acid methyl ester, and the inability to utilize quinic acid and L-tartrate.

A selection of 50 phenotypic characteristics was used to construct a UPGMA dendrogram (Fig. 3) in PAUP $4.0 \mathrm{~b} 10$ (Swofford, 2000). The dendrogram showed a clear distinction of $T$. ptyseos and the 'Japanese' species from the Pantoea 'core' species, lending further support for the reclassification of these three species in the genus Tatumella, and the description of a novel species for the strains causing pink disease of pineapple.

\section{Conclusions}

The many previous rearrangements observed in the 'Erwinia herbicola-Enterobacter agglomerans complex' were, 
Table 3. Selected phenotypic characteristics useful for distinguishing Tatumella species from Pantoea species

Taxa: 1, T. ptyseos (1 strain); 2, T. citrea comb. nov. (1 strain); 3, T. morbirosei sp. nov. (2 strains); 4, T. punctata comb. nov. (7 strains); 5, T. terrea comb. nov. (3 strains); 6, P. agglomerans (3 strains); 7, P. ananatis (4 strains); 8, P. anthophila (2 strains); 9, P. deleyi (1 strain); 10, P. dispersa (2 strains); 11, P. eucalypti (2 strains); 12, P. stewartii subsp. stewartii (1 strain); 13, P. stewartii subsp. indologenes (2 strains); 14, P. vagans (7 strains). All data presented were generated during this study, except for 2-ketogluconate dehydrogenase for which the results were taken from Kageyama et al. (1992) and Bouvet et al. (1989). +, Positive; -, negative; (+), weakly positive; v, variable reaction; ND, not determined.

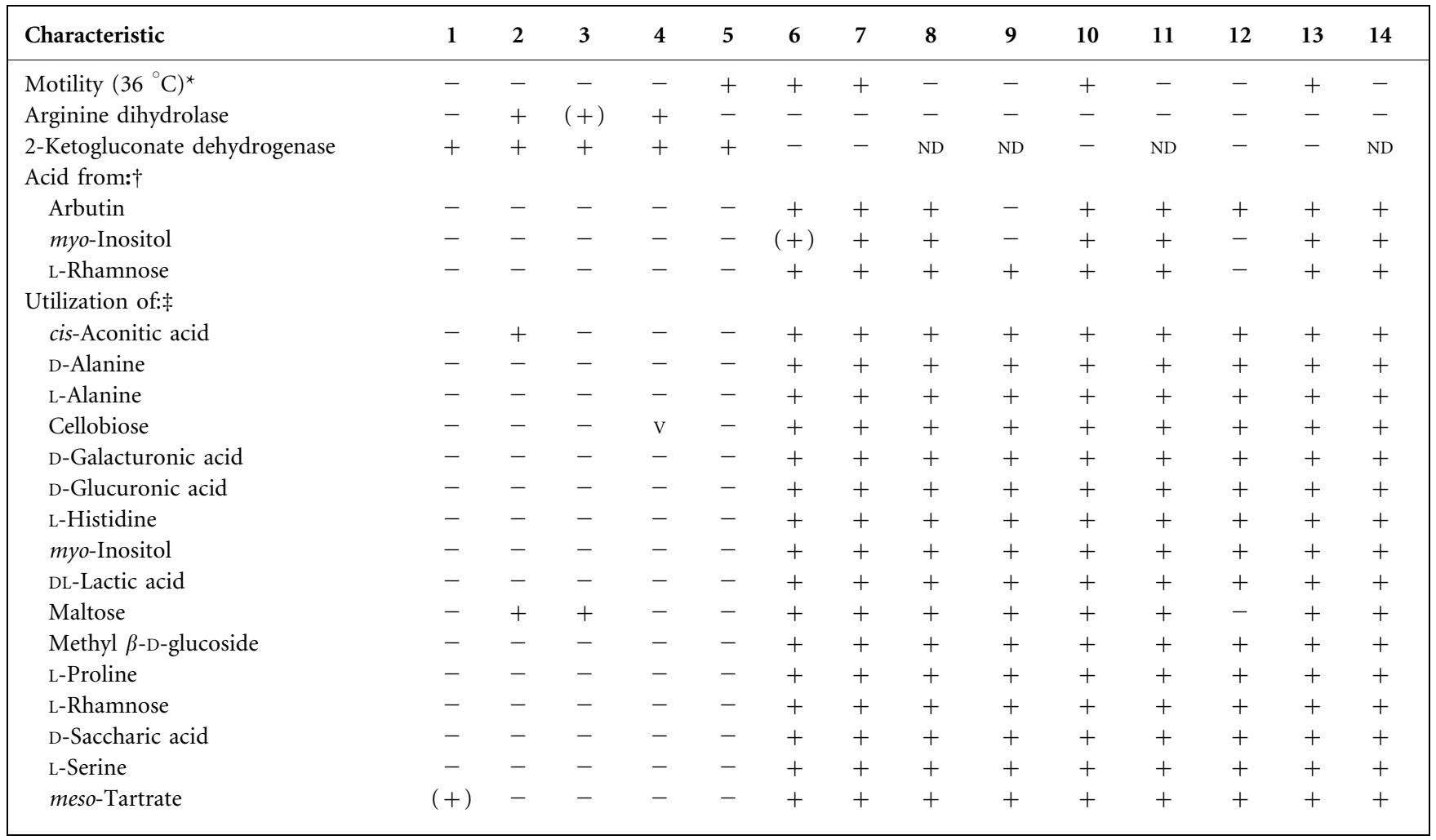

${ }^{\star} T$. ptyseos is non-motile at $36{ }^{\circ} \mathrm{C}$ but many strains are motile at $25{ }^{\circ} \mathrm{C}$. Flagella of Tatumella species are polar, subpolar or lateral rather than peritrichous like Pantoea species.

$\dagger$ API $50 \mathrm{CHB} / \mathrm{E}$.

$\ddagger$ Biotype 100, GN2 MicroPlate.

for the most part, based on DNA-DNA hybridization data, biochemical characterization and protein profiling. When $P$. citrea, $P$. punctata and $P$. terrea were described as belonging to the genus Pantoea, molecular techniques such as $16 \mathrm{~S}$ rRNA gene sequencing and MLSA were not readily accessible. With rapid gene sequencing now a reality, it is possible to observe true phylogentic relationships and to resolve evident taxonomic issues.

The 16S rRNA gene and MLSA trees showed a clear division of the Pantoea 'core' species from the 'Japanese' species and T. ptyseos. Furthermore, MLSA group J (strains causing pink disease of pineapple) was shown to cluster independently from the type strain of $P$. citrea in both phylogenetic trees. These results were supported equally by DNA-DNA hybridization values, which shared a high correlation with MLSA data (Brady et al., 2008), and phenotypic data. Although the genus Tatumella is reported to have few distinguishing phenotypic properties (Farmer, 2005), a number of biochemical characteristics were identified that are shared by the 'Japanese' species and can be used to differentiate these species from Pantoea (see Table 3).

An important characteristic that distinguishes $P$. citrea, $P$. punctata, P. terrea, T. ptyseos and MLSA group J from Pantoea species is their ability to produce 2 -ketogluconate dehydrogenase, which oxidizes 2-ketogluconate to DKGA. The production of DKGA is responsible for the discolouration of fruit tissue typical of pink disease of pineapple (Pujol \& Kado, 2000), and therefore plays an important role in disease expression. Noticeably, not one Pantoea 'core' species has this ability (Bouvet et al., 1989). Several objections for not including the 'Japanese' species in the genus Tatumella were stated in the original description, despite a personal communication from P. Grimont suggesting that the 'Japanese' species were phenotypically similar to Tatumella (cited by Kageyama et al., 1992). These included acid production from D-xylose and Larabinose, arginine dihydrolase and phenylalanine deaminase activity, methyl red and Voges-Proskauer reactions, 
Table 4. Phenotypic characteristics that distinguish $T$. citrea comb. nov., T. morbirosei sp. nov., T. punctata comb. nov. and T. terrea comb. nov. from each other and from T. ptyseos

Strains: 1, T. ptyseos LMG $7888^{\mathrm{T}}$ and LMG 23565; 2, T. citrea LMG $22049^{\mathrm{T}}$; 3, T. morbirosei LMG $23360^{\mathrm{T}}$ and LMG 23359; 4, T. punctata LMG 22050 ${ }^{\mathrm{T}}$, LMG 22097, LMG 22098 and LMG 23563; 5, T. terrea LMG $22051^{\mathrm{T}}$ and LMG 23564. +, Positive; (+), weakly positive; -, negative. All data were generated in this study.

\begin{tabular}{|c|c|c|c|c|c|}
\hline Characteristic & 1 & 2 & 3 & 4 & 5 \\
\hline Arginine dihydrolase & - & + & $(+)$ & + & - \\
\hline Phenylalanine deaminase & + & - & + & - & - \\
\hline \multicolumn{6}{|l|}{ Acid from: } \\
\hline Starch & - & - & + & - & - \\
\hline D-Mannitol & - & + & + & - & - \\
\hline Raffinose & - & - & - & + & - \\
\hline Sucrose & + & - & - & + & + \\
\hline \multicolumn{6}{|l|}{ Utilization of: } \\
\hline Adonitol & - & - & + & - & - \\
\hline L-Arabinose & - & + & + & - & - \\
\hline Dextrin & - & + & + & - & - \\
\hline Erythritol & - & + & + & - & - \\
\hline Formic acid & - & + & $(+)$ & - & + \\
\hline Gentiobiose & - & $(+)$ & - & + & - \\
\hline Lactulose & - & + & - & - & - \\
\hline Pyruvic acid methyl ester & - & $(+)$ & $(+)$ & - & + \\
\hline Quinic acid & + & - & - & - & - \\
\hline L-Tartrate & + & - & - & - & - \\
\hline Trigonelline & - & - & + & - & - \\
\hline
\end{tabular}

aesculin hydrolase activity, citrate utilization and lower DNA G + C content. However, closer examination of all available data revealed that all taxa were positive for acid production from D-xylose and L-arabinose, methyl red and Voges-Proskauer reactions and citrate utilization. $T$. ptyseos and $P$. terrea are both negative for arginine dihydrolase activity, whereas $P$. citrea and $P$. punctata are both positive. The DNA G $+\mathrm{C}$ content of T. ptyseos was $51.7-52.1 \mathrm{~mol} \%$, which is slightly higher than those of the 'Japanese' species, which range from 49.8 to $52.8 \mathrm{~mol} \%$. However, the DNA G + C contents of Pantoea 'core' species ranged from 53 to $61 \mathrm{~mol} \%$, which is considerably higher. Therefore the current data, both phylogenetic and phenotypic, support the transfer of the 'Japanese' species from the genus Pantoea to the genus Tatumella.

We propose to transfer $P$. citrea, $P$. punctata and $P$. terrea to the genus Tatumella as Tatumella citrea comb. nov., Tatumella punctata comb. nov. and Tatumella terrea comb. nov. We further propose Tatumella morbirosei sp. nov. for strains LMG 23359 and LMG $23360^{\mathrm{T}}$, the causal agent of pink disease of pineapple.

\section{Emended description of the genus Tatumella Hollis, Hickman \& Fanning 1982}

Tatumella (Ta.tum.el'la. N.L. fem. dim. n. Tatumella named to honour Harvey Tatum, an American bacteriolo- gist who made many contributions to our understanding of the classification and identification of fermentative and nonfermentative bacteria of medical importance.) The description below is based on the data of Hollis et al. (1981), Kageyama et al. (1992) and this paper.

Gram-negative, non-capsulated, non-spore-forming small rods that are $0.6-1.2 \times 0.9-3.0 \mu \mathrm{m}$ in size. Cells are motile by means of polar, subpolar or lateral flagella or non-motile at $36{ }^{\circ} \mathrm{C}$. Facultatively anaerobic, fermentative, catalasepositive (weak and slow) and oxidase-negative. Nonpigmented, or pale beige to pale orange. Glucose dehydrogenase, gluconate dehydrogenase and 2-ketogluconate dehydrogenase are produced. Reduce nitrate to nitrite. Indole, urease and gelatin tests are negative. Positive for VogesProskauer (Coblentz), methyl red and citrate (Simmons); phenylalanine, arginine dihydrolase and ONPG tests are variable. Negative for $\mathrm{H}_{2} \mathrm{~S}$ (TSI), lysine decarboxylase, ornithine decarboxylase, tryptophan deaminase, $\mathrm{KCN}$ test, lipase and DNase. Acid is produced from L-arabinose, Dgalactose, D-glucose, glycerol, D-mannitol, D-mannose, melibiose, D-ribose, trehalose and D-xylose (variable reaction for T. morbirosei), but not from amygdalin, dulcitol, erythritol, glutarate, glycogen, histamine, myo-inositol, methyl $\alpha$-Dglucoside, propionate, L-rhamnose, sorbitol or L-sorbose. $\mathrm{N}$ Acetyl-D-glucosamine, 4-aminobutyrate, L-asparagine, Laspartic acid, bromosuccinic acid, D-fructose, fumarate, $\beta$ galactopyranoside, D-gluconic acid, $\alpha$-D-glucose 1-phosphate, $\alpha$-D-glucose 6-phosphate, L-glutamic acid, glycerol, inosine, 5-ketogluconate, D-mannose, L-proline, D-psicose, D-ribose, succinic acid, trehalose, thymidine and uridine are utilized as sole sources of carbon and energy. Susceptible to many antibiotics. Isolated from human clinical samples, fruit and soil. The $\mathrm{G}+\mathrm{C}$ content of the DNA ranges from 49.8 to $53 \mathrm{~mol} \%$. The type species is Tatumella ptyseos Hollis, Hickman \& Fanning 1982.

\section{Description of Tatumella citrea (Kageyama et al. 1992) comb. nov.}

Tatumella citrea (ci'tre.a. L. fem. adj. citrea belonging to the citrus tree).

Basonym: Pantoea citrea Kageyama et al. 1992.

Cells are Gram-negative, short rods $(0.8-1.2 \times 1.0-3.0 \mu \mathrm{m})$ occurring singly or in pairs, non-motile and non-sporeforming. Colonies are pale beige to pale orange, round, convex and smooth with entire margins. Nicotinic acid or nicotinamide are required for growth. Facultatively anaerobic, oxidase-negative, catalase-positive and glucose dehydrogenase, gluconate dehydrogenase and 2-ketogluconate dehydrogenase are produced. Indole, urease and phenylalanine deaminase are negative, whereas arginine dihydrolase is positive. Reduces nitrate to nitrite. Acid is produced from L-arabinose, D-fucose, D-galactose, D-glucose, glycerol, maltose, D-mannose, D-mannitol, D-tagatose and trehalose, but not from starch, raffinose or sucrose. The following carbon sources are utilized at $28{ }^{\circ} \mathrm{C}: \mathrm{N}$-acetyl-D-glucos- 


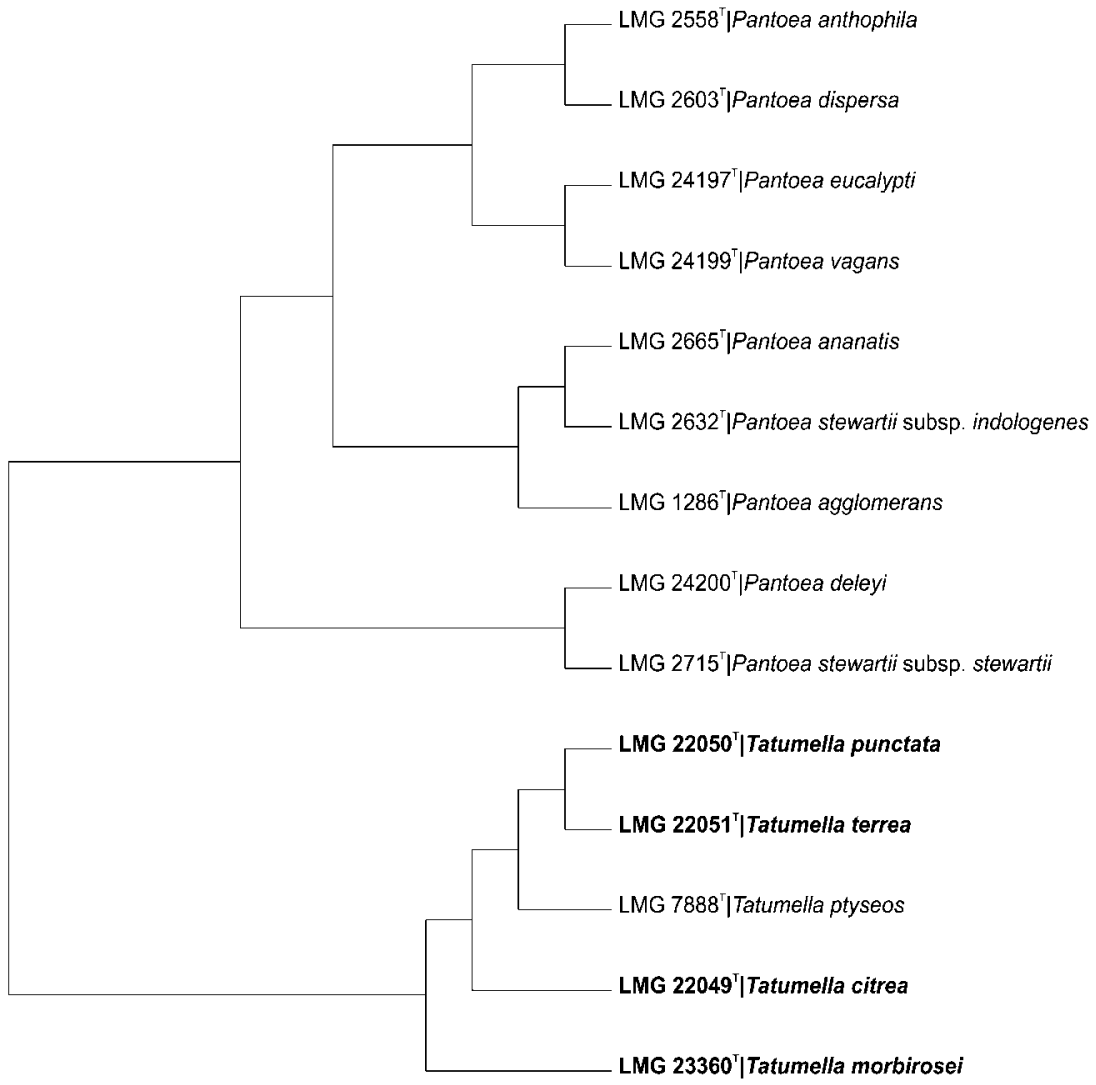

Fig. 3. UPGMA dendrogram constructed from 50 phenotypic characteristics useful for the differentiation of the 'core' Pantoea species from species of the genus Tatumella. amine, cis-aconitic acid, L-arabinose, L-asparagine, Laspartic acid, citrate, dextrin, erythritol, formic acid, Dfructose, D-galactose, gentiobiose (weak), D-gluconic acid, D-glucose, 5-ketogluconate, lactose, lactulose, D-malate, maltose, maltotriose, D-mannitol, pyruvic acid methyl ester, succinic acid and D-tagatose. The following carbon sources are not utilized at $28{ }^{\circ} \mathrm{C}$ : D-adonitol, L-alanine, Darabinose, betaine, dulcitol, L-fucose, methyl $\alpha$-D-glucoside, methyl $\beta$-D-glucoside, D-galacturonic acid, D-glucuronic acid, glutarate, histidine, myo-inositol, melibiose, L-proline, propionate, quinic acid, raffinose, L-rhamnose, D-sorbitol, L-serine, sucrose, L-tartrate, meso-tartrate and trigonelline. The DNA G $+\mathrm{C}$ content of the type strain is $49.8 \mathrm{~mol} \%$.

The type strain, SHS $2003^{\mathrm{T}} \quad\left(=\right.$ ATCC $31623^{\mathrm{T}}=\mathrm{BD}$ $875^{\mathrm{T}}=$ CCUG $30156^{\mathrm{T}}=$ CIP $105599^{\mathrm{T}}=\mathrm{DSM} 13699^{\mathrm{T}}=\mathrm{JCM}$ $8882^{\mathrm{T}}=$ LMG $22049^{\mathrm{T}}$ ), was isolated from mandarin orange in Japan.

\section{Description of Tatumella punctata (Kageyama et al. 1992) comb. nov.}

Tatumella punctata (punc.ta' ta. L. n. punctum a point; N.L. fem. adj. punctata full of points).

Basonym: Panteo punctata Kageyama et al. 1992.

Cells are Gram-negative, short rods $(1.1-1.2 \times 1.3-2.3 \mu \mathrm{m})$ occurring singly or in pairs, non-motile and non-spore- forming. Colonies are pale beige to pale orange, round, convex and smooth with entire margins. Nicotinic acid or nicotinamide are required for growth. Facultatively anaerobic, oxidase-negative, catalase-positive and glucose dehydrogenase, gluconate dehydrogenase and 2-ketogluconate dehydrogenase are produced. Indole, urease and phenylalanine deaminase are negative, whereas arginine dihydrolase is positive. Reduces nitrate to nitrite. Acid is produced from L-arabinose, D-fructose, D-fucose, D-galactose, Dglucose, glycerol, D-mannose, raffinose, sucrose and trehalose, but not from starch or D-mannitol. The following carbon sources are utilized at $28{ }^{\circ} \mathrm{C}$ : $\mathrm{N}$-acetylD-glucosamine, D-arabinose, L-asparagine, L-aspartic acid, cellobiose (variable), citrate, D-fructose, D-galactose, gentiobiose, D-gluconic acid, D-glucose, 5-ketogluconate, Dmannitol, D-mannose, succinic acid, sucrose and trehalose. The following carbon sources are not utilized at $28{ }^{\circ} \mathrm{C}$ within 3-6 days: cis-aconitic acid, D-adonitol, L-alanine, Larabinose, D-arabitol, L-arabitol, betaine, dextrin, dulcitol, erythritol, formic acid, L-fucose, D-galacturonic acid, Dglucuronic acid, methyl $\alpha$-D-glucoside, methyl $\beta$-D-glucoside, glutarate, histidine, myo-inositol, lactose, lactulose, maltose, maltotriose, melibiose, L-proline, propionate, pyruvic acid methyl ester, quinic acid, raffinose, Lrhamnose, D-sorbitol, L-serine, L-tartrate, meso-tartrate and trigonelline. The DNA $\mathrm{G}+\mathrm{C}$ content of the type strain is $50.7 \mathrm{~mol} \%$. 
The type strain, SHS $2006^{\mathrm{T}} \quad\left(=\mathrm{ATCC} \quad 31626^{\mathrm{T}}=\mathrm{BD}\right.$ $876^{\mathrm{T}}=$ CCUG $30159^{\mathrm{T}}=$ CIP $105598^{\mathrm{T}}=\mathrm{DSM} 13700^{\mathrm{T}}=\mathrm{JCM}$ $8885^{\mathrm{T}}=$ LMG $22050^{\mathrm{T}}$ ), was isolated from mandarin orange in Japan.

\section{Description of Tatumella terrea (Kageyama et al. 1992) comb. nov.}

Tatumella terrea (ter're.a. L. fem. adj. terrea of the earth).

Basonym: Panteoa terrea Kageyama et al. 1992.

Cells are Gram-negative, short rods $(0.8-0.9 \times 1.2-$ $2.0 \mu \mathrm{m}$ ) occurring singly or in pairs, motile by means of one or two lateral flagella and non-spore-forming. Colonies are pale beige to pale orange, round, convex and smooth with entire margins. Nicotinic acid or nicotinamide is required for growth. Facultatively anaerobic, oxidase-negative, catalase-positive and glucose dehydrogenase, gluconate dehydrogenase and 2ketogluconate dehydrogenase are produced. Indole, urease, phenylalanine deaminase and arginine dihydrolase are negative. Reduces nitrate to nitrite. Acid is produced from L-arabinose, $\mathrm{D}$-fructose, $\mathrm{D}$-galactose, $\mathrm{D}$ glucose, glycerol, D-mannose, sucrose and trehalose, but not from starch, D-mannitol or raffinose. The following carbon sources are utilized at $28{ }^{\circ} \mathrm{C}: \mathrm{N}$-acetyl-D-glucosamine, L-asparagine, L-aspartic acid, citrate, D-fructose, formic acid, D-galactose, D-gluconic acid, D-glucose, 5ketogluconate, D-mannose, pyruvic acid methyl ester, succinic acid and trehalose. The following carbon sources are not utilized at $28{ }^{\circ} \mathrm{C}$ : cis-aconitic acid, D-adonitol, Lalanine, D-arabinose, L-arabinose, D-arabitol, L-arabitol, betaine, cellobiose, dextrin, dulcitol, erythritol, L-fucose, D-galacturonic acid, gentiobiose, D-glucuronic acid, methyl $\alpha$-D-glucoside, methyl $\beta$-D-glucoside, glutarate, histidine, myo-inositol, lactose, lactulose, maltose, maltotriose, melibiose, L-proline, propionate, quinic acid, raffinose, L-rhamnose, D-sorbitol, L-serine, sucrose, Ltartrate and trigonelline. The DNA G $+\mathrm{C}$ content of the type strain is $52.8 \mathrm{~mol} \%$.

The type strain, SHS $2008^{\mathrm{T}} \quad\left(=\mathrm{ATCC} \quad 31628^{\mathrm{T}}=\mathrm{BD}\right.$ $877^{\mathrm{T}}=$ CCUG $30161^{\mathrm{T}}=$ CIP $105600^{\mathrm{T}}=$ DSM $13701^{\mathrm{T}}=\mathrm{JCM}$ $8887^{\mathrm{T}}=$ LMG $22051^{\mathrm{T}}$ ), was isolated from soil in Japan.

\section{Description of Tatumella morbirosei sp. nov.}

Tatumella morbirosei (mor.bi.ró.se.i. L. n. morbus disease; L. adj. roseus rosy pink; N.L. gen. n. morbirosei of the pink disease, referring to the causal agent of pink disease of pineapple).

Cells are Gram-negative, short rods $(0.8-1.2 \times 1.0-3.0 \mu \mathrm{m})$ occurring singly or in pairs, non-motile and non-sporeforming. Colonies are pale beige, round, convex and smooth with entire margins. Facultatively anaerobic, oxidase-negative, catalase-positive and glucose dehydrogenase, gluconate dehydrogenase and 2-ketogluconate dehydrogenase are produced. Indole and urease are negative, whereas phenylalanine deaminase is positive and arginine dihydrolase is weakly positive. Reduces nitrate to nitrite. Acid is produced from starch, Larabinose, D-fucose, D-fructose, D-galactose, D-glucose, glycerol, 5-ketogluconate, melibiose, D-mannitol, D-mannose, D-tagatose and trehalose, but not from raffinose or sucrose. The following carbon sources are utilized at $28{ }^{\circ} \mathrm{C}$ : $\mathrm{N}$-acetyl-D-glucosamine, D-adonitol, D-arabinose, L-arabinose, L-asparagine, L-aspartic acid, citrate, dextrin, erythritol, formic acid (weak), D-fructose, D-galactose, Dgluconic acid, D-glucose, 5-ketogluconate, D-malate, maltose, maltotriose, D-mannitol, D-mannose, pyruvic acid methyl ester (weak), succinic acid, D-tagatose, trehalose and trigonelline. The following carbon sources are not utilized at $28{ }^{\circ} \mathrm{C}$ : cis-aconitic acid, L-alanine, L-arabitol, betaine, cellobiose, dulcitol, L-fucose, gentiobiose, methyl $\alpha$-D-glucoside, methyl $\beta$-D-glucoside, D-galacturonic acid, D-glucuronic acid, glutarate, histidine, myo-inositol, lactose, lactulose, melibiose, L-proline, propionate, quinic acid, raffinose, L-rhamnose, D-sorbitol, L-serine, L-tartrate and meso-tartrate. The DNA G $+\mathrm{C}$ content of the type strain is $50.2 \mathrm{~mol} \%$.

The type strain, LMG $23360^{\mathrm{T}} \quad\left(=\mathrm{BD} \quad 878^{\mathrm{T}}=\mathrm{NCPPB}\right.$ $\left.4036^{\mathrm{T}}=\mathrm{CMC}^{\mathrm{T}}\right)$, was isolated from pineapple in the Philippines.

\section{Acknowledgements}

This study was partially supported by the South African-Flemish Bilateral Agreement, the National Research Foundation (NRF), the Tree Protection Co-operative Programme (TPCP) and the THRIP support programme of the Department of Trade and Industry, South Africa. The BCCM/LMG Bacteria collection is supported by the Federal Public Planning Service-Science Policy, Belgium. The authors wish to thank Katrien Engelbeen for technical assistance and Professor J. P. Euzéby for suggesting the name 'morbirosei'.

\section{References}

Bouvet, O. M. M., Lenormand, P. \& Grimont, P. A. D. (1989). Taxonomic diversity of the D-glucose oxidation pathway in the Enterobacteriaceae. Int J Syst Bacteriol 39, 61-67.

Brady, C. L., Cleenwerck, I., Venter, S. N., Vancanneyt, M., Swings, J. \& Coutinho, T. A. (2008). Phylogeny and identification of Pantoea species associated with plants, humans and the natural environment based on mulitlocus sequence analysis (MLSA). Syst Appl Microbiol 31, 447-460.

Brosius, J., Palmer, M. L., Kennedy, P. J. \& Noller, H. F. (1978). Complete nucleotide sequence of a $16 \mathrm{~S}$ ribosomal RNA gene from Escherichia coli. Proc Natl Acad Sci U S A 75, 4801-4805.

Cha, J.-S., Pujol, C., Ducusin, A. R., Macion, E. A., Hubbard, C. H. \& Kado, C. I. (1997). Studies on Pantoea citrea, the causal agent of pink disease of pineapple. J Phytopathol 145, 313-319.

Cleenwerck, I., Vandemeulebroecke, K., Janssens, D. \& Swings, J. (2002). Re-examination of the genus Acetobacter, with descriptions of Acetobacter cerevisiae sp. nov. and Acetobacter malorum sp. nov. Int $J$ Syst Evol Microbiol 52, 1551-1558.

Coenye, T., Falsen, E., Vancanneyt, M., Hoste, B., Govan, J. R. W., Kersters, K. \& Vandamme, P. (1999). Classification of Alcaligenes 
faecalis-like isolates from the environment and human clinical samples as Ralstonia gilardii sp. nov. Int J Syst Bacteriol 49, 405-413.

Delétoile, A., Decré, D., Courant, S., Passet, V., Audo, J., Grimont, P., Arlet, G. \& Brisse, S. (2009). Phylogeny and identification of Pantoea species and typing of Pantoea agglomerans strains by multilocus gene sequencing. J Clin Microbiol 47, 300-310.

Ezaki, T., Hashimoto, Y. \& Yabuuchi, E. (1989). Fluorometric deoxyribonucleic acid-deoxyribonucleic acid hybridization in microdilution wells as an alternative to membrane filter hybridization in which radioisotopes are used to determine genetic relatedness among bacterial strains. Int J Syst Bacteriol 39, 224-229.

Farmer, J. J., III (2005). Genus XXXVII. Tatumella Hollis, Hickman and Fanning 1982, 267 ${ }^{\mathrm{VP}}$ (Effective publication: Hollis, Hickman, Fanning, Farmer, Weaver and Brenner 1981, 86) (Group EF-9 Hollis, Hickman, Fanning, Brenner and Weaver 1980). In Bergey's Manual of Systematic Bacteriology, 2nd edn, vol. 2, The Proteobacteria, part B, The Gammaproteobacteria, pp. 825-826. Edited by D. J. Brenner, N. R. Krieg, J. T. Staley \& G. M. Garrity. New York: Springer.

Gavini, F., Mergaert, J., Beji, A., Mielcarek, C., Izard, D., Kersters, K. \& De Ley, J. (1989). Transfer of Enterobacter agglomerans (Beijerinck 1988) Ewing and Fife 1972 to Pantoea gen. nov. as Pantoea agglomerans comb. nov. and description of Pantoea dispersa sp. nov. Int J Syst Bacteriol 39, 337-345.

Goris, J., Suzuki, K., De Vos, P., Nakase, T. \& Kersters, K. (1998). Evaluation of a microplate DNA-DNA hybridization method compared with the initial renaturation method. Can J Microbiol 44, 1148-1153.

Grimont, P. A. D. \& Grimont, F. (2005). Genus XXIII. Pantoea Gavini, Mergaert, Beji, Mielcarek, Izard, Kersters and De Ley 1989b, $343^{\mathrm{VP}}$ emend. Mergaert, Verdonck and Kersters 1993, 171. In Bergey's Manual of Systematic Bacteriology, 2nd edn, vol. 2, The Proteobacteria, part B, The Gammaproteobacteria, pp. 713-720, Edited by D. J. Brenner, N. R. Krieg, J. T. Staley \& G. M. Garrity. New York: Springer.

Guindon, S. \& Gascuel, O. (2003). A simple, fast, and accurate algorithm to estimate large phylogenies by maximum likelihood. Syst Biol 52, 696-704.

Hollis, D. G., Hickman, F. W., Fanning, G. R., Farmer, J. J., III, Weaver, R. E. \& Brenner, D. J. (1981). Tatumella ptyseos gen. nov., sp. nov., a member of the family Enterobacteriaceae found in clinical samples. J Clin Microbiol 14, 79-88.
Kageyama, B., Nakae, M., Yagi, S. \& Sonoyama, T. (1992). Pantoea punctata sp. nov., Pantoea citrea sp. nov., and Pantoea terrea sp. nov. isolated from fruit and soil samples. Int J Syst Bacteriol 42, 203210.

Mergaert, J., Verdonck, L. \& Kersters, K. (1993). Transfer of Erwinia ananas (synonym, Erwinia uredovora) and Erwinia stewartii to the genus Pantoea emend. as Pantoea ananas (Serrano 1928) comb. nov. and Pantoea stewartii (Smith 1898) comb. nov., respectively, and description of Pantoea stewartii subsp. indologenes subsp. nov. Int $J$ Syst Bacteriol 43, 162-173.

Mesbah, M., Premachandran, U. \& Whitman, W. B. (1989). Precise measurement of the $\mathrm{G}+\mathrm{C}$ content of deoxyribonucleic acid by highperformance liquid chromatography. Int J Syst Bacteriol 39, 159167.

Niemann, S., Pühler, A., Tichy, H.-V., Simon, R. \& Selbitschka, W. (1997). Evaluation of the resolving power of three different DNA fingerprinting methods to discriminate among isolates of a natural Rhizobium meliloti population. J Appl Microbiol 82, 477-484.

Paradis, S., Biossinot, M., Paquette, N., Bélanger, S. D., Martel, E. A., Boudreau, D. K., Picard, F. J., Ouellette, M., Roy, P. H. \& Bergeron, M. G. (2005). Phylogeny of the Enterobacteriaceae based on genes encoding elongation factor Tu and F-ATPase $\beta$-subunit. Int J Syst Evol Microbiol 55, 2013-2025.

Posada, D. \& Crandall, K. A. (1998). MODELTEST: testing the model of DNA substitution. Bioinformatics 14, 817-818.

Pujol, C. J. \& Kado, C. I. (2000). Genetic and biochemical characterization of the pathway in Pantoea citrea leading to pink disease of pineapple. J Bacteriol 182, 2230-2237.

Swofford, D. L. (2000). PAUP*: Phylogenetic analysis using parsimony (and other methods). Sunderland, MA: Sinauer Associates.

Thompson, J. D., Gibson, T. J., Plewniak, F., Jeanmougin, F. \& Higgins, D. G. (1997). The CLUSTAL_X windows interface: flexible strategies for multiple sequence alignment aided by quality analysis tools. Nucleic Acids Res 25, 4876-4882.

Wilson, K. (1987). Preparation of genomic DNA from bacteria. In Current Protocols in Molecular Biology, pp. 2.4.1-2.4.5. Edited by F. M. Ausubel, R. Brent, R. E. Kingston, D. D. Moore, J. G. Seidman, J. A. Smith \& K. Struhl. New York: Green Publishing \& Wiley-Interscience. 